\title{
ANALISA PENGARUH SERVICE QUALITY TERHADAP BEHAVIORAL INTENTIONS DENGAN PERCEIVED VALUE DAN CUSTOMER SATISFACTION SEBAGAI VARIABEL INTERVENING PADA PENDIDIKAN TINGGI
}

\author{
Trixie Nova Bella Tandijaya \\ Pengamat Pendidikan di Surabaya \\ E-mail: nova.trixie@gmail.com
}

\begin{abstract}
Abstrak:Pentingnya menjaga mutu pendidikan sebuah negara, membuat pendidikan di Indonesia juga terus melakukan perbaikan baik dari tingkat Sekolah Dasar hingga tingkat Universitas. Di tingkat Universitas saja, semakin muncul persaingan antara Universitas Swasta maupun Negeri untuk menghasilkan semakin banyak lulusan yang berkualitas. Sehingga banyak Universitas mulai memikirkan strategi untuk dapat memenangkan persaingan.Salah satunya dengan menjaga Service Quality yang mereka berikan. Penelitian ini bertujuan untuk mengetahui pengaruh Service Quality terhadap Behavioral Intention atau kecenderungan berperilaku, dengan perceived value dan customer satisfaction sebagai variabel intervening pada Pendidikan Tinggi Surabaya. Penelitian ini dilaksanakan dengan menyebarkan kuisioner kepada 100 responden mahasiswa Pendidikan tinggi angkatan 2012-2016. Hasil penelitian ini menunjukan bahwa service quality berpengaruh secara positif dan signifikan terhadap perceived value dan behavioral intentions, perceived value berpengaruh secara positif dan signifikan terhadap customer satisfaction dan behavioral intentions, dan customer satisfaction berpengaruh secara secara positif dan signifikan terhadap behavioral intentions. Hasil dari penelitian ini juga menunjukan bahwa perceived value dan customer satisfaction sebagai variable intervening tidak berhasil memediasi hubungan antara service quality dan behavioral intentions.
\end{abstract}

Kata kunci: Service quality, perceived value, customer satisfaction, behavioral intention.

\begin{abstract}
The importance of maintaining the quality of education of a country, making education in Indonesia also continues to make improvements both from the Elementary School level to the University level. At the University level alone, there is increasing competition between the State and Private Universities to produce more and more qualified graduates. So many universities are starting to think of strategies to win the competition. One of them by maintaining the Service Quality they provide. This study aims to determine the effect of Service Quality on Behavioral Intention or the tendency to behave, with perceived value and customer satisfaction as intervening variable high education students 2012-2016. The results of this study indicate that service quality has a positive and significant influence on perceived value and behavioral intentions, perceived value positively and significantly influence customer satisfaction and behavioral intentions, and customer satisfaction positively and significantly influence behavioral intentions. The results of this study also show that perceived value and customer satisfaction as intervening variables do not successfully mediate the relationship between service quality and behavioral intentions.
\end{abstract}

Keywords: Service quality, perceived value, customer satisfaction, behavioral intention.

\section{PENDAHULUAN}

Perbaikan kualitas sumber daya manusia erat kaitannya dengan perbaikan kualitas pendidikan suatu negara.Penyediaan kualitas pendidikan yang baik merupakan kunci menciptakan generasi berkualitas. Hal inilah yang sedang dihadapi juga oleh Indonesia. Menurut data dalam Education For All (EFA) Global Monitoring Report 2011: The Hidden Crisis, Armed Conflict and Education yang dikeluarkan Organisasi Pendidikan, Ilmu Pengetahuan, dan Kebudayaan Perserikatan Bangsa-Bangsa (UNESCO), indeks pembangunan pendidikan atau education development index (EDI)tahun 2014 berada di peringkat 57 dari 115 negara ("Indonesia Peringkat ke- 57 EDI dari 115 Negara Tahun 2014,” n.d.).
Meskipun mutu pendidikan tergolong rendah, namun pertumbuhan perguruan tinggi di Indonesia cukup pesat.Selain jumlah perguruan tingggi yang terus meningkat jumlah mahasiswa juga mengalami peningkatan seperti di Jawa Timur misalnya. Menurut Badan Pusat Statistik (BPS) tahun 2015 jumlah mahasiswa total 109.666 orang yang terdaftar di 6 Perguruan Tinggi Negeri dan di 129 Perguruan Tinggi Swasta ("Jumlah Perguruan Tinggi 1, Mahasiswa, dan Tenaga Edukatif (Negeri dan Swasta) di Bawah Kementrian Agama Menurut Provinsi 2013/ 2014 dan 2014/2015," n.d.).

Terdapat peluang yang besar bagi perguruan tinggi swasta untuk menarik lebih banyak calon pendaftar dibandingkan perguruan tinggi negeri melihat jumlah perguruan tinggi swasta yang jauh lebih 
banyak. Sehingga akan menimbulkan persaingan yang cukup ketat di antara perguruan tinggi swasta untuk meningkatkan kualitas dengan cara memberikan pelayanan- pelayanan yang bisa memenuhi kebutuhan dan memusakan mahasiswanya.

Ada 2 dimensi kualitas pelayanan yaitu kualitas fungsional dan kualitas teknis (Grönroos, 1984). Kemudian, alat pengukuran yang paling populer untuk kualitas pelayanan dikembangkan oleh Parasuraman et al, (1985) dimana awalnya terdiri dari sepuluh dimensi, yaitu, tangibility, reliability, responsiveness, communication, credibility, security, competence, courtesy, understanding dan access dimensions, yang didefinisikan ulang dan diubah menjadi lima dimensi yang berguna, yaitu, tangibles, reliability, responsiveness, assurance dan empathy pada tahun 1988.

Menurut Schofield dan Breen (2004) ada kebutuhan untuk menyediakan lingkungan yang mempertemukan ekspektasi konsumen dan akibatnya akan menghasilkan nilai yang dirasakan pelanggan lebih tinggi. Sebuah cara yang efektif untuk menilai perceived value atau nilai yang dirasakanadalah keputusan pelanggan di pembelian berikutnya yang baik itu mengulangi untuk menggunakan produk atau layanan sebelumnya atau beralih ke produk atau layanan lain. Untuk itulah kepuasan konsumen harus tercapai dan dapat dijaga. Dengan kata lain, semakin puas pelanggan, semakin besar retensi pelanggan (Anderson dan Sullivan, 1993; Fornell, 1992) dan kesediaan untuk merekomendasikan (Zeithaml dan Bitner, 1996).

Kepuasaan konsumen akan terjadi ketika nilai dan customer service yang disediakan dalam pengalaman sesuai atau melebihi harapan konsumen. Kepuasan pelanggan indeks model dari Eropa dan Amerika menunjukkan bahwa kualitas layanan merupakan komponen kepuasan (Fornell et al., 1996). Bagozzi (1992) mengusulkan bahwa evaluasi kualitas layanan dari produk atau jasa dimana pertemuan mengarah ke penilaian kepuasan emosional yang pada gilirannya mendorong behavioral intentions. Anderson (1992) menemukan persepsi kualitas layanan, kepuasan mereka dan niat perilaku mereka, termasuk kata-kata positif, rekomendasi kepada orang lain, mengunjungi lagi penyedia, dll.

Zeithaml dan Bitner (1996) mengidentifikasi dua dimensi untuk mengukur niat perilaku yaitu menguntungkan dan tidak menguntungkan. Niat perilaku yang menguntungkan maksudnya adalah pelanggan akan menyampaikan kata-kata yang positif, niat pembelian kembali dan loyalitas (Ladhari, 2008; Zeithaml dan Bitner, 1996), sedangkan niat perilaku yang tidak menguntungkan cenderung menyebar kata-kata negatif dan menyampaikan pengalaman negatif mereka untuk pelanggan lain dan niat untuk beralih ke pesaing. Nilai yang dirasakan pelanggan telah diterima sebagai prediksi yang dapat diandalkan dari kepuasan pelanggan dan niat perilaku pembelian konsumen (Andreassen dan Lindestad, 1992; Choi, 2004; McDougall dan Levesque, 2000; Sweeney, 1999; Wu et al, 2014).

Oleh karena itu peneliti ingin membuktikan Pengaruh Service Quality Terhadap Behavioral Intentions Dengan Perceived Value dan Customer Satisfaction Sebagai Variabel Intervening Pada Pendidikan Tinggi.

\section{TINJAUAN PUSTAKA}

\section{Service Quality}

Kualitas layanan berasal dari perbandingan antara apa yang pelanggan rasa penjual akan tawarkan (yaitu harapan mereka) dengan kinerja pelayanan penjual sebenarnya (Gronroos 1982). Gagasan bahwa kualitas pelayanan merupakan fungsi dari kesenjangan kinerja yang diharapkan diperkuat oleh studi eksplorasi berbasis luas yang dilakukan oleh Parasuraman et al. (1985).

Menurut Parasuraman et al. (1988) kualitas pelayanan adalah persentase perbedaan antara harapan pelanggan mengenai produk dan pengalaman natural yang diperoleh setelah memanfaatkan layanan atau mengkonsumsi produk. Faktor yang paling disarankan dalam konteks ini adalah kualitas yang dirasakan pelanggan seperti kualitas pelayanan, dimana harga produk dan jasa sesuai dengan fasilitas yang disediakan oleh perusahaan. Lalu, kualitas pelayanan adalah memenuhi kebutuhan dan harapan konsumen (Lewis dan Mitchell, 1990). Persepsi pelanggan benar-benar tergantung pada "interaktif proses, kegiatan dan tindakan yang sedang berlangsung antara pelanggan dan penyedia layanan" (Svensson, 2006).

Ada lima dimensi pengukuran dari model kualitas pelayana dari Parasuraman et al. (1988), yaitu:

1. Tangible adalah penampilan fasilitas fisik, peralatan, personil, dan bahan-bahan tertulis.

2. Reliability kemampuan untuk melakukan layanan yang dijanjikan secara terpercaya dan akurat.

3. Responsiveness adalah kesediaan untuk membantu pelanggan dan memberikan layanan yang cepat

4. Assurance adalah pengetahuan karyawan dan kesopanan dan kemampuan mereka untuk menginspirasi kepercayaan dan keyakinan.

5. Empathy berarti peduli dan perhatian individual yang diberikan kepada pelanggan. 


\section{Perceived Value}

Zeithaml (2009, p. 14) mendefinisikan perceived value sebagai keseluruhan penilaian konsumen dari kegunaan produk atau jasa berdasarkan persepsi tentang apa yang diterima dan apa yang diberikan. Perceived value dapat didefinisikan sebagai hasil dari perbandingan pribadi antara manfaat yang dirasakan secara keseluruhan dan pengorbanan dirasakan atau biaya yang dibayar oleh pelanggan (Zeithaml, 2009).

Menurut Sweeney (2002) perlunya untuk menyediakan lingkungan pelanggan yang memenuhi harapan mereka dan akibatnya akan menghasilkan nilai yang dirasakan pelanggan lebih tinggi.Menurut Gronroos (1984, p. 37) mendefinisikan perceived value adalah layanan yang diberikan sebagai hasil dari proses evaluasi, dimana konsumen membandingkan harapannya dengan persepsi tentang pelayanan yang diterima.

Beberapa upaya penting untuk menguji usulan teoritis ini adalah dari Sweeney dan Soutar (2001), yang melalui studi empiris yang berbeda merancang skala pengukuran nilai yang dirasakan (PERVAL). Analisis reliabilitas dan validitas dilakukan dalam merancang PERVAL, yang mengakibatkan pengurangan lima dimensi yang diusulkan oleh Sheth et al. (1991a, b) menjadi tiga yaitu:

1. Fungsional

Dimensi fungsional adalah berkaitan dengan utilitas yang berasal dari atribut produk dan jasa. Pelanggan memperoleh nilai dari atribut seperti kualitas produk, kualitas layanan, atau harga (Sweeney et al., 1999). Ini adalah analisis ekonomi dan rasional membandingkan manfaat dan pengorbanan.

2. Sosial

Lapierre (2000) mendefinisikan nilai sosial sebagai citra berdasarkan reputasi dan kredibilitas dan dampak sosial yang dimiliki perusahaan.

\section{Emosional}

Dimensi emosional dari nilai yang dirasakan berasal dari perasaan dan emosi bahwa produk atau jasa menghasilkan dampak kepada pembeli.

\section{Customer Satisfaction}

Pelanggan yang puas lebih akan menjadi setia atau bahkan menganjurkan sebuah organisasi, memiliki reaksi minimal untuk perubahan harga dan kurang kemungkinan untuk beralih ke pesaing (Ferrel dan Hartline, 2010). Di antara model kepuasan, paradigma harapan diskonfirmasi (EDP) telah mendominasi riset kepuasan konsumen (Radder dan Han, 2015).
Kitapci et al. (2008) menyatakan lebih lanjut bahwa kepuasan pelanggan melibatkan kognitif dan komponen afektif yang mempengaruhi pembentukan kepuasan. Hal ini sejalan dengan definisi oleh Worsfold et al. (1994, p. 25), yang menggambarkan kepuasan pelanggan "sebagai evaluasi kognitif dan afektif pelanggan berdasarkan pengalaman pribadi di semua episode layanan dalam hubungan. Komponen afektif merujuk pada perasaan konsumen terhadap suatu stimuli atau kejadian, misalnya apakah konsumen menyukai sebuah produk atau tidak. Komponen kognitif mengacu pada pemikiran konsumen, misalnya apa yang dipercaya konsumen dari suatu produk. Kognitif terdiri dari lima proses mental, yaitu: memahami, mengevaluasi, merencanakan, memilih, dan berpikir.

Berikut indikator pengukuran dari kepuasan pelanggan (Ziethaml, Bitner, \& Gremler, 2009):

\section{Fulfillment}

Adalah respon untuk memenuhi kebutuhan pelanggan dengan menilai fitur dari produk atau jasa, atau produk atau jasa itu sendiri, dan memberi tingkat menyenangkan dari pemenuhan konsumsi.

2. Pleasure

Kepuasan juga dapat dikaitkan dengan perasaan senang untuk layanan yang membuat konsumen merasa nyaman atau berhubungan dengan rasa bahagia.

\section{Relief}

Rasa lega yang dirasakan konsumen terhadap hal negatif yang berkurang dari produk atau jasa.

\section{Ambivalence}

Keadaan ketika ada campuran pengalaman positif dan negatif yang terkait dengan produk atau layanan.

\section{Behavioral Intention}

Konsep behavioral intentions mengacu pada kemungkinan pelanggan kembali ke jasa perusahaan yang mereka telah gunakan, atau menyebarkan informasi positif tentang perusahaan ke keluarga dan teman-teman (Othman et al, 2013; Wu, 2015). Tindakan ini hasil dari kepuasan pelanggan (Othman et al., 2013). Sebaliknya, ketidakpuasan menciptakan pengaruh negatif pada behavioral intentions (Kitapci et al., 2014). Beberapa studi (Chen dan Chen, 2010) menemukan bahwa nilai pengalaman mendorong niat perilaku positif, integrasi dari membangun pengalaman akan mempengaruhi niat perilaku positif.

Dalam penelitian ini, "behavioral intentions" memiliki dimensi sebagai berikut:

1) Loyalitas;

Dipahami dalam penelitian ini sebagai komitmen yang dipegang untuk mengulang pembelian layanan disukai (Oliver, 1997). Loyalitas dapat diwujudkan dengan meningkatkan bisnis dengan 
perusahaan di masa depan dan dengan mengekspresikan preferensi untuk itu (Zeithaml et al., 1996).

2) Rekomendasi;

Rekomendasi didefinisikan oleh Amoah, et al. (2016) sebagai kesiapan untuk berkomunikasi tentang penyedia layanan, oleh pelanggan lama yang sudah ada yang dianggap tidak mendapatkan keuntungan moneter dari melakukan hal ini". Ulasan pelanggan ini mewakili nilai untuk penyedia layanan dan bertindak sebagai duta dari perusahaan (Feinberg et al, 2000; Anderson,, 2000).

3) Membayar harga premium.

Kesediaan untuk membayar lebih adalah niat pelanggan untuk membayar harga yang lebih tinggi dari pesaing biaya untuk manfaat yang pelanggan terima dari penyedia layanan (Zeithaml et al., 1996).

\section{Kerangka Konseptual}

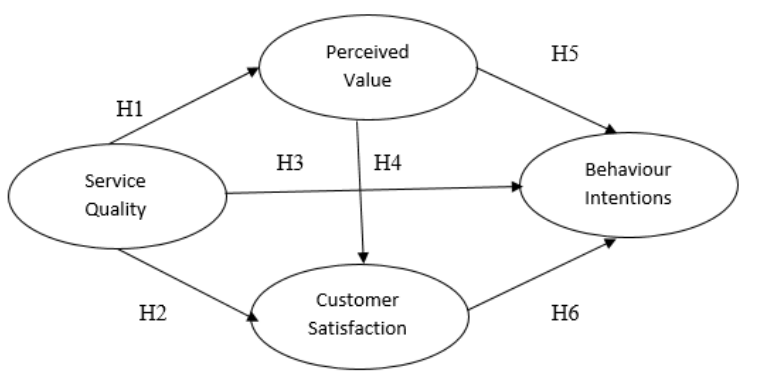

Gambar 1. Kerangka Konseptual

Hipotesa

H1: Adanya hubungan positif antara kualitas pelayanan dan nilai yang dirasakan pelanggan.

$\mathrm{H} 2$ : Adanya hubungan positif antara kualitas pelayanan dan kepuasan pelanggan.

H3: Adanya hubungan positif antara kualitas pelayanan terhadap niat perilaku pelanggan.

H4: Adanya hubungan positif antara nilai yang dirasakan pelanggan terhadap kepuasan pelanggan.

H5: Adanya hubungan positif antara nilai yang dirasakan pelanggan terhadap niat perilaku pelanggan.

\section{METODE PENELITIAN}

\section{Populasi}

Populasi adalah wilayah generalisasi yang terdiri atas objek/subyek yang mempunyai kualitas dan karakteristik tertentu yang sudah ditetapkan untuk dipelajari dan kemudian ditarik kesimpulannya
(Sugiyono, 2014). Dalam penelitian ini, populasi yang akan diteliti adalah mahasiswa Pendidikan tinggi.

\section{Sampel}

Sampel adalah subkelompok populasi yang dipilih untuk berpartisipasi dalam penelitian ini (Malhotra, 2010). Teknik sampling yang digunakan untuk penarikan sampel adalah Nonprobability Sampling. Nonprobability sampling adalah teknik pengambilan sampel yang tidak memberi peluang/kesempatan sama bagi setiap unsur atau anggota populasi untuk dipilih menjadi sampel.

Teknik penarikan sampel yang digunakan peneliti adalah quota sampling dimana teknik ini digunakan untuk menentukan sampel dari populasi yang mempunyai ciri-ciri tertentu sampai jumlah (kuota) yang diinginkan (Sugiyono, 2014). Adapun sampel yang dipilih adalah mahasiswa Pendidikan tinggi angkatan 2012-2016.

\section{Definisi Operasional Variabel}

Service Quality (X1)

a. Tangible: Diukur melalui fasilitas yang disediakan, dan akses informasi di papan pengumuman

b. Reliability: Di ukur melalui kejelasan materi kuliah, transparansi nilai, konsistensi jadwal kuliah dan mengajar, ketepatan waktu penyampaian informasi, dan kemampuan staf akademik melayani administrasi mahasiswa.

c. Responsiveness: Diukur melalui prosedur layanan tidak menyulitkan mahasiswa, menyediakan dosen bimbingan bagi mahasiswa, komunikasi yang cepat antara dosen dan mahasiswa, serta staf yang menunjukan kesediaan membantu mahasiswa.

d. Assurance: Diukur melalui Staf Administrasi akademik (Tata Usaha) santun dalam melayani, Permasalahan dan keluhan mahasiswa mampu di tangani, dosen mampu menciptakan kenyamanan dalam perkuliahan, dosen menguasai materi perkuliahan, dan perlakuan adil yang diterima mahasiswa.

e. Empathy: Diukur melalui kemudahan berkonsultasi, dosen menunjukan kepedulian terhadap masalah mahasiswa, staf yang melayani dengan semangat, cepat, dan ramah, serta dosen yang menjaga kerahasiaan informasi dari mahasiswa.

\section{Perceived Value (Y1)}

a. Fungsional: Diukur melalui manfaat yang dirasakan mahasiswa, dan kesesuaian biaya dengan kualitas yang diterima mahasiswa. 
b. Sosial: Diukur melalui kenyamanan yang dirasakan mahasiswa, dosen mampu memotivasi mahasiswa, dan mampu memberikan nilai-nilai kehidupan.

c. Emosional: Diukur melalui rasa bangga, lingkungan yang nyaman, dan motivasi yang dirasakan mahasiswa selama proses perkuliahan.

Customer Satisfaction (Y2)

a. Fulfillment: Diukur melalui terpenuhinya kebutuhan pendidikan yang dirasakan mahasiswa selama proses perkuliahan.

b. Pleasure: Diukur melalui suasana menyenangkan yang dirasakan mahasiswa selama proses perkuliahan.

c. Relief: Diukur melalui pemahaman mahasiswa tentang kesulitan selama kuliah adalah bagian dalam proses perkuliahan.

d. Ambivalence: Diukur melalui pengalaman unik yang dimiliki mahasiswa selama proses perkuliahan.

\section{Behavioral Intention (Z1)}

a. Loyalitas: Diukur melalui kemauan mahasiswa memberikan kontribusi dan terlibat dengan kegiatan Pendidikan tinggi demu kemajuan kedepan.

b. Rekomendasi: Diukur melalui kemauan mahasiswa menyarankan dan mendorong teman/ kerabat untuk berkuliah di Pendidikan tinggi, serta kecenderungan mahasiswa memberikan respon positif kepada teman/kerabatnya.

c. Membayar harga premium: Diukur melalui sukarela mahasiswa mengikuti semua proses pembayaran dan kesesuaian pengorbanan (biaya) yang diberikan dengan nilai yang dirasakan.

\section{Path Analysis}

Pengujian hipotesis yang ada pada penelitian ini dilakukan dengan menggunakan teknik pathanalysis untuk menujukkan adanya hubungan yang kuat dengan variabel-variabel yang diuji. Teknik pathanalysis digunakan untuk melukiskan dan menguji model hubungan antar variabel yang berbentuk sebab akibat (Sugiyono, 2014). Teknik ini merupakan pengembangan korelasi yang diurai menjadi beberapa interpretasi akibat yang ditimbulkannya.

Pengujuan statistik pada model pathanalysis dilakukan dengan menggunakan metode partialleastsquare. Partial Least Square (PLS) adalah bagian dari SEM. PLS merupakan teknik terbaru yang banyak diminati karena tidak membutuhkan distribusi normal atau dapat dikatakan sebuah penelitian dengan jumlah sampel yang sedikit. Salah satu kelebihan
PLS-SEM adalah mampu menangani model yang kompleks dengan multiple variabel eksogen dan endogen dengan banyak indikator, dapat digunakan pada sampel dengan jumlah kecil, dan data distribusi yang condong.

\section{ANALISA DAN PEMBAHASAN}

\section{Evaluasi Path Coefficient dan Coefficient of Deter- mination $\left(R^{2}\right)$}

Evaluasi path coefficient digunakan untuk menunjukan seberapa kuat pengaruh variabel independen kepada variabel dependen. Sedangkan coefficient determination digunakan untuk mengukur seberapa banyak variabel endogen dipengaruhi oleh variabel lainnya. Didalam marketing research, nilai $\mathrm{R}^{2}$ diatas 0,75 keatas dikategorikan substansial, $0,50-0,75$ artinya sedang, dan 0,25-0,50 artinya lemah.

Pada analisapath coefficient ini telah terbukti bahwa customer satisfaction dan perceived value merupakan variabel interveiningyang dimana tidak memperkuat hubungan antara service quality dengan behavioral intentions sebesar 0,264 yang dimana merupakan hasil perkalian antara 0,740 dan 0,358 serta $-0,0386$ yang dimana merupakan hasil perkalian antara $-0,209$ dan 0,185 .

Hubungan service quality terhadap behavioral intentions secara langsung menunjukan angka 0,417 dimana angka yang menunjukan hubungan secara langsung ini lebih besar daripada menggunakan perceived value dan customer satisfaction sebagai variabel intervening yang hanya 0,264 dan $-0,0386$.

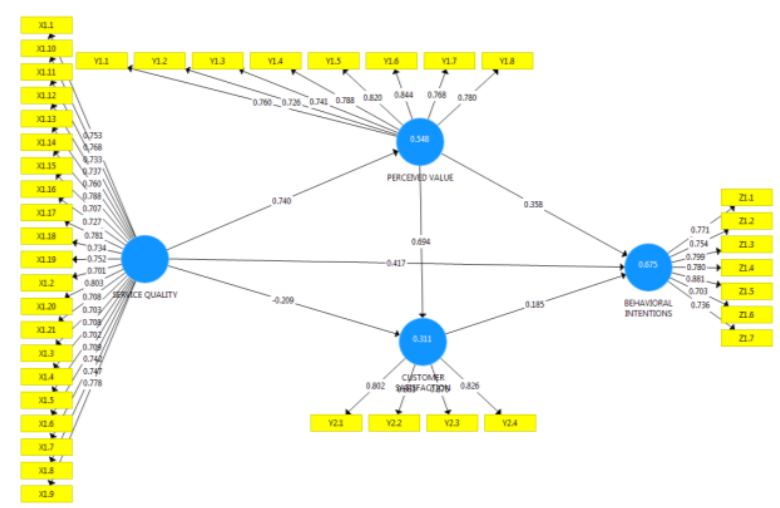

Gambar 1. Path Coefficient dan Coefficient of Determination

Gambar 1 merupakan bukti bahwa dalam penelitian ini perceived value dan customer satisfaction tidak memperkuat hubungan antara variabel independen terhadap variabel dependen. Melainkan hubungan secara langsung antara variabel independen ke variabel dependen lebih kuat. 
Selain itu, hampir keseluruhan variabel dalam model ini memiliki path coefficient dengan angka yang positif kecuali variabel customer satisfaction yang memiliki path coefficient negatif.Sehingga jika semakin besar nilai positif path coefficient pada suatu variabel independen terhadapvariabel dependen tersebut, maka semakin kuat juga pengaruh antara variabel independen terhadap variabel dependen tersebut, dan begitu juga sebaliknya apabila nilai path coefficient dari variabel negatif maka semakin lemah juga pengaruhnya.

Nilai coefficient of determination $\left(R^{2}\right)$ yang didalam gambar ditunjukan pada angka di dalam lingkaran perceived value yang dipengaruhi oleh service quality sebesar 0,548 . Artinya variabel service quality mempengaruhi perceived value sebesar $54,8 \%$ sedangkan 44,2\% lainnya dipengaruhi oleh variabel lain diluar penelitian. Lalu variabel customer satisfaction yang dipengaruhi yang dipengaruhi oleh service quality dan perceived value sebesar 0,311. Artinya variabel service quality dan perceived value mempengaruhi customer satiscation sebesar $31,1 \%$ sedangkan $68,9 \%$ lainnya dipengaruhi oleh variabel lain di luar penelitian. Lalu, variabel behavioral intentions yang dipengaruhi oleh service quality, perceived value, dan customer satisfaction sebesar 0,711. Artinya, variabel service quality, perceived value, dan customer satisfaction mempengaruhi behavioral intentions sebesar 71,1\% sedangkan 29,9\% lainnya dipengaruhi oleh variabel lain diluar penelitian.

\section{T-Statistics dan Uji Hipotesis}

Nilai T-statistic diperoleh dari prosedur bootstrapping, yang dimana nilai ini digunakan untuk menarik kesimpulan pada suatu uji hipotesis. Nilai $T$ statistic dengan level signifikansi $5 \%$ menjelaskan bahwa inner modelakan signifikan jika nilai T-statistic lebih besar dari 1.96 .

\begin{tabular}{|l|c|c|c|c|c|}
\hline & $\begin{array}{c}\text { Original } \\
\text { Sample (O) }\end{array}$ & $\begin{array}{c}\text { Sample } \\
\text { Mean (M) }\end{array}$ & $\begin{array}{c}\text { Standard } \\
\text { Deviation } \\
\text { (STDEV) }\end{array}$ & $\begin{array}{c}\text { T Statistics } \\
(\text { O/STDEV) }\end{array}$ & P Values \\
\hline $\begin{array}{l}\text { Customer } \\
\text { Satisfaction (Y2) } \\
\rightarrow \quad \text { Behavioral } \\
\text { Intentions (Z1) }\end{array}$ & 0,185 & 0,187 & 0,085 & 2,175 & 0,030 \\
\hline $\begin{array}{l}\text { Perceived Value } \\
\text { (Y1) } \rightarrow \text { Behavioral } \\
\text { Intentions (Z1) }\end{array}$ & 0,358 & 0,358 & 0,136 & 2,621 & 0,009 \\
\hline $\begin{array}{l}\text { Perceived Value } \\
\text { (Y1) } \rightarrow \text { Customer } \\
\text { Satisfaction (Y2) }\end{array}$ & 0,694 & 0,696 & 0,140 & 4,970 & 0,000 \\
\hline $\begin{array}{l}\text { Service Quality } \\
\text { (X1) } \rightarrow \text { Behavioral } \\
\text { Intentions (Z1) }\end{array}$ & 0,417 & 0,416 & 0,123 & 3,391 & 0,001 \\
\hline $\begin{array}{l}\text { Service Quality } \\
\text { (X1) } \rightarrow \text { Customer } \\
\text { Satisfaction (Y2) }\end{array}$ & $-0,209$ & $-0,209$ & 0,149 & 1,403 & 0,161 \\
\hline $\begin{array}{l}\text { Service Quality } \\
\text { (X1) } \rightarrow \text { Perceived } \\
\text { Value (Y1) }\end{array}$ & 0,740 & 0,745 & 0,058 & 12,714 & 0,000 \\
\hline
\end{tabular}

Gambar 2.T-statistic
T-statistic pada pengaruh customer satisfaction terhadap behavioral intentions menunjukan 2,175 yang artinya customer satisfactions berpengaruh singnifikan terhadap behavioral intentions. T-statistic pada pengaruh perceived value terhadap behavioral intentions menunjukan 2,621 yang artinya perceived value berpengaruh signifikan terhadap behavioral intentions. T-statistic pada pengaruh perceived value terhadap customer satisfaction menunjukan 4,970 yang artinya perceived value berpengaruh signifikan terhadap customer satisfaction.

$T$-statistic pada pengaruh service quality terhadap behavioral intentions menunjukan 3,391 yang artinya service quality berpengaruh signifikan terhadap behavioral intentions. T-statistic pada pengaruh service quality terhadap customer satisfaction menunjukan 1,403 yang artinya service quality tidak berpengaruh signifikan terhadap customer satisfaction.T-statistic pada pengaruh service quality terhadap perceived value menunjukan 12,714 yang artinya service quality berpengaruh signifikan terhadap perceived value.

\section{Service Quality terhadap Perceived Value}

Penelitian ini memiliki hasil bahwaservice quality Pendidikan tinggi memiliki pengaruh terhadap perceived value secara signifikan dengan nilai uji $T$ statistic $>1.96$ yaitu 12,941 .

Penelitian ini mempunyai hasil yang menunjukan bahwa service quality berpengaruh signifikan terhadap perceived value yang dimana hal ini sesuai dengan pendapat bahwa kualitas pelayanan memiliki dampak yang tinggi pada nilai yang dirasakan pelanggan (Zameer, Tara, Kausar, \& Mohsin, 2015).

Kualitas pelayanan yang diberikan mampu meningkat nilai yang dirasakan oleh mahasiwa seperti adanya manfaat yang dirasakan, biaya yang dikeluarkan sesuai dengan kualitas yang diterima, mahasiwa merasa nyaman, mahasiswa merasa bangga, mahasiswa merasa termotivasi, sampai pada dosen yang mampu memberikan motivasi dan memberikan nilainilai kehidupan pada mahasiswa.

Hubungan antara service quality dan perceived value juga dapat dibuktikan memiliki hubungan yang signifikan, sehingga nilai yang dirasakan mahasiswa tinggi karena didukung dengan kualitas pelayanan yang baik dari Pendidikan tinggi .

\section{Service Quality terhadap Customer Satisfaction}

Hasil penelitian ini juga menunjukan bahwa service quality tidak berpengaruh terhadap customer satisfaction. Pada hasil penelitian ini diketahui bahwa 
tidak adanya pengaruh secara signifikan tersebut merupakan hasil uji $T$-statistics dengan nilai 1,635 yaitu dibawah 1,96. Sehingga diketahui bahwa kualitas pelayanan Pendidikan tinggi tidak mempengaruhi kepuasaan mahasiswanya.

Lalu apabila dilihat dari nilai path coefficient, hubungan dari kualitas pelayanan menuju customer satisfaction sebesar $-0,238$. Terdapat hubungan negatif yang menunjukan bahwa kualitas pelayanan sebaliknya melemahkan kepuasan mahasiswa. Jika dilihat dari nilai path coefficient kepuasan mahasiswa lebih condong di pengaruhi oleh nilai yang dirasakan oleh mahasiswa. Lemahnya hubungan kualitas pelayanan dengan kepuasan juga terjadi pada penelitian yang dilakukan oleh (Feinberg et al., 2000) pada sebuah call centre bank mengungkapkan bahwa kualitas operasional dari call centre tidak atau hanya lemah hubungannya dengan kepuasan pelanggan.

\section{Service Quality terhadap Behavioral Intentions}

Hasil dari penelitian ini menunjukan bahwa service quality memiliki pengaruh terhadap behavioral intentions secara signifikan dengan nilai uji $T$ statistic $>1.96$ yaitu 3,291. Penelitian ini mempunyai hasil yang menunjukan bahwa service quality berpengaruh signifikan terhadap behavioral intentions yang dimana hal ini sesuai dengan pendapat (Ladhari \& Morales, 2008) bahwa kualitas pelayanan berpengaruh posistif pada niat perilaku. Dapat dikatakan bahwa dengan memberikan kualitas pelayanan dengan baik maka dengan sendirinya mahasiswa akan memiliki kencederungan memberikan rekomendasi, loyal dan bersedia membayar dengan harga premium.

Seperti yang terjadi pada Pendidikan tinggi apabila kualiatas pelayanan yang diberikan dirasa baik, maka mahasiswa dengan rela akan merekomendasikan kepada teman/kerabat terdekat. Namun ada beberapa dimensi dari kualitas pelayanan yang belum makismal dilakukan oleh pendidikan tinggi, sehingga membuat dimensi niat perilakunya rendah, seperti keinginan untuk memberi rekomendasi dan mendorong teman atau kerabat berkuliah.

\section{Perceived Value terhadap Customer Satisfaction}

Hasil dari penelitian ini menunjukan bahwa perceived value memiliki pengaruh terhadap customer satisfaction secara signifikan dengan nilai uji $T$ statistic >1.96 yaitu 4,970. Hal ini sesuai dengan penelitian yang dilakukan oleh $(\mathrm{Wu}, 2014)$ dimana peningkatan nilai yang dirasakan kemudian menghasilkan kepuasan pelanggan berdasarkan pada hubungan positif antara nilai yang dirasakan dan kepuasan pelanggan. Sehingga dapat dikatakan bahwa sewaktu nilai yang dirasakan mahasiswa baik maka secara otomatis mahasiswa tersebut akan merasakan kepuasan.

Seperti yang terjadi di Pendidikan tinggi mahasiswa secara umum merasakan manfaat berkuliah, biaya yang dikeluarkan sesuai dengan kualitas yang diterima, merasa nyaman selama proses perkuliahan, dosen mampu memotivasi dan memberikan nilai-nilai kepada mahasiswa, dan mahasiswa merasa termotivasi selama proses perkuliahan. Adanya nilai yang dirasakan baik sehingga membuat mahasiswa cukup puas berada di Pendidikan tinggi.

Hubungan perceived value dan customer satisfaction juga dapat dibuktikan memiliki hubungan yang signifikan, sehingga kepuasan mahasiswa yang dirasakan tinggi karena adanya nilai yang dirasakan selama proses perkuliahan di Pendidikan tinggi.

\section{Perceived Value terhadap Behavioral Intentions}

Penelitian ini memiliki hasil bahwa perceived value mahasiswa Pendidikan tinggi memiliki pengaruh terhadap behavioral intentions secara signifikan dengan nilai uji $T$-statistic $>1.96$ yaitu 2,621.

Penelitian ini mempunyai hasil yang menunjukkan bahwa perceived value berpengaruh signifikan terhadap behavioral intentions yang dimana hal ini sesuai dengan pendapat (Amoah, Radder, \& van Eyk, 2016) bahwa nilai yang dirasakan pelanggan memiliki pengaruh posistif terhadap kepuasan pelanggan dan berpengaruh pada niat perilaku pelanggan.

Pendidikan tinggi sudah cukup berhasil menciptakan kesesuaian nilai yang dirasakan mahasiswa dengan yang diharapkan. Terbukti dengan hasil penelitian dari kuesioner bahwa mahasiswa tidak bermasalah dengan biaya yang dikeluarkan karena merasakan manfaatnya berkuliah di Pendidikan tinggi sehingga mempengaruhi behavioral intention dari mahasiswa.

Hubungan antara perceived value dan behavioral intentions juga dapat dibuktikan memiliki hubungan yang signifikan, sehingga behavioral intentions yang tercipta di mahasiswa Pendidikan tinggi cukup tinggi karena adanya nilai positif yang dirasakan.

\section{Customer Satisfaction terhadap Behavioral Inten- tions}

Penelitian ini memiliki hasil bahwa customer satisfaction Pendidikan tinggi memiliki pengaruh terhadap behavioral intentions secara signifikan dengan nilai uji $T$-statistic $>1.96$ yaitu 2,175.

Penelitian ini mempunyai hasil yang menunjukkan bahwa customer satisfaction berpengaruh signifi- 
kan terhadap behavioral intentions yang dimana hal ini sesuai dengan pendapat (Jandavath \& Byram, 2016) bahwa saat kepuasan pelanggan berhasil tercipta maka menghasilkan niat pelanggan yang positif.

\section{Perceived Value Tidak Memediasi Hubungan Service Quality Terhadap Behavioral Intentions}

Penelitian ini bertujuan untuk melihat pengaruh service quality terhadap behavioral intention dengan menggunakan perceived value dan customer satisfaction sebagai variabel interveining. Perceived value memiliki hubungan yang signifikan terhadap service quality dan behavioral intentions. Namun dalam Pendidikan tinggi hubungan antara service quality dan behavioral intentions secara langsung lebih kuat.

Hubungan service quality dan behavioral intention ini lebih kuat karena beberapa tahun terakhir cukup banyak mahasiswa yang merasa kualitas pelayanan Pendidikan tinggi mengalami penurunan dibandingkan sewaktu awal masuk kuliah dan kurang sesuai dengan apa yang diharapkan sehingga membuat mereka sangat sensitif menilai kualitas pelayanan dimana hal ini sangat mempengaruhi niat perilaku mereka. Hal ini terlihat dari hasil kuesioner yang sudah dibagikan selama penelitian ini dilakukan, bahwa kecenderungan mahasiswa Pendidikan tinggi untuk memberikan rekomendasi atau mendorong teman/kerabat mereka cukup rendah. Dengan demikian, nilai yang dirasakan tidak mempengaruhi secara signifikan niat perilaku mahasiswa, sama halnya dengan penelitian yang dilakukan oleh (Worsfold Kate, 2016) pada sebuah hotel bahwa persepsi tamu terhadap nilai yang dirasakan tidak mempengaruhi niatnya untuk kembali.

\section{KESIMPULAN DAN SARAN}

Berdasarkan hasil penelitian mengenai Analisa pengaruh Service quality terhadap Behavioral Intentions dengan Perceived Value dan Customer satisfaction sebagai variable intervening pada pendidikan tinggi menunjukan bahwa service quality berpengaruh secara positif dan signifikan terhadap perceived value dan behavioral intentions, perceived value berpengaruh secara positif dan signifikan terhadap customer satisfaction dan behavioral intentions, dan customer satisfaction berpengaruh secara secara positif dan signifikan terhadap behavioral intentions. Hasil dari penelitian ini juga menunjukan bahwa perceived value dan customer satisfaction sebagai variable intervening tidak berhasil memediasi hubungan antara service quality dan behavioral intentions.
Berdasarkan hasil penelitian dan pembahasan diatas, peneliti akan mengajukan beberapa saran yaitu Pendidikan tinggi perlu meningkatkan transparansi nilai dari dosen yang dirasa mahasiswa masih kurang transparan. Selain itu, waktu penyampaian informasi kepada mahasiswa juga harus diperbaiki karena beberapa mahasiswa merasa terkadang informasi yang disampaikan cukup mendadak, prosedur layanan yang diterapkan Pendidikan tinggi juga perlu diperbaiki karena dirasa cukup menyulitkan mahasiswa.Lalu, perlu juga staf administarasi Pendidikan tinggi lebih ramah, semangat, dan cepat dalam melayani mahasiswa. Terakhir, Pendidikan tinggi perlu menambah tenaga pengajar guna mengefektifkan proses perkuliahan melihat beberapa mahasiswa merasa kebutuhan pendidikannya kurang terpenuhi. Selain itu, perlu juga melakukan evaluasi lebih mendalam terkait kualitas tenaga pengajar.

\section{DAFTAR PUSTAKA}

Amoah, F., Radder, L., \& van Eyk, M. (2016). Perceived experience value, satisfaction and behavioural intentions. African Journal of Economic and Management Studies, 7(3), 419-433. https://doi.org/10.1108/AJEMS-10-2015-0121

Anderson, E.W. and Sullivan, M. (1993), "The antecedents and consequences of customer.

Anderson, J., Thomson, B.L. and Wynstra, F. (2000), "Combining value and price to make purchase decisions in business markets", International Journal of Research in Marketing, 17(4), pp. 307-29.

Anderson, J.C., Jain, D.C. and Chintagunta, P.K. (1992), "Customer value assessment in business markets: a state-ofpractice study", Journal of Business to Business Marketing, 1(1), pp. 3-30.

Bagozzi, R.P. (1992), "The self regulation of attitudes, intentions, and behavior", Social Psychology Quarterly, 55, pp. 178-204.

Chen, C.F. and Chen, F.S. (2010), "Experience quality, perceived value, satisfaction and behavioural intentions for heritage tourists", Tourism Management, 31(1), pp. 29-35.

Choi, K.S., Cho, W.H., Sunhee, L., Hanjoon, L. and Kim, C. (2004), "The relationship among quality, value, satisfaction and behavioral intention in healthcare provider choice: a South Korean study", Journal of Business Research, 57(8), pp. 913-921

Feinberg, R.A., Kim, I-S., Hokama, L., de Ruyter, K. and Keen, C. (2000), "Operational determinants of caller satisfaction in the call center", International Journal of Service Industry Management, 11(2), pp. 31-41. 
Ferrel, O.C. and Hartline, B. (2010), Marketing Strategy, 5th ed., Cengage Learning, New York, NY

Grönroos, C. 1984, "A service quality model and its marketing implications", European Journal of Marketing, 18(4), pp. 836-844.

Indonesia Peringkat ke-57 EDI dari 115 Negara Tahun 2014.(n.d.). Retrieved February 20, 2017, from https://www.kemenkopmk.go.id/artikel/ indonesia-peringkat-ke-57-edi-dari-115-negaratahun-2014

Jandavath, R. K. N., \& Byram, A. (2016). Healthcare service quality effect on patient satisfaction and behavioural intentions in corporate hospitals in India.International Journal of Pharmaceutical and Healthcare Marketing, 10(1), 48-74. https://doi.org/10.1108/IJPHM-07-2014-0043

Jumlah Perguruan Tinggi 1, Mahasiswa, dan Tenaga Edukatif (Negeri dan Swasta) di Bawah Kementrian Agama Menurut Provinsi 2013/2014 dan 2014/2015.(n.d.). Retrieved February 20, 2017, from https://www.bps.go.id/linkTabelStatis/ view/ id/1840

Kitapci, O., Akdogan, C. and Dortyol, I.T. (2014), "The impact of service quality dimensions on patient satisfaction, repurchase intentions and word-of-mouth communication in the public healthcare industry", Procedia-Social and Behavioral Sciences, 148, August, pp. 161-169.

Ladhari, R. (2008), "Alternative measures of service quality: a review", Managing Service Quality, 18(1), pp. 65-86.

Ladhari, R., \& Morales, M. (2008). Perceived service quality, perceived value and recommendation: A study among Canadian public library users. Library Management, 29(4/5), 352-366. https://doi.org/10.1108/01435120810869129

Lapierre, J. (2000), "Customer-perceived value in industrial context", Journal of Business \& Industrial Marketing, 15(Nos 2/3), pp. 122-40.

Malhotra, N. K. (2010). Marketing research an applied orientation (sixth edit).Pearson Prentice Hall.

McDougall, G.H. and Levesque, T.J. (2000), "Customer satisfaction with service: putting perceived value into the equation", Journal of Services Marketing, 14(5), pp. 392-410.

Othman, Z., Zahari, M.S.M. and Radzi, S.M. December (2013), "Customer behavioral intention: influence of service delivery failures and service recovery in Malay restaurants", Procedia-Social and Behavioral Sciences, 105, pp. 115-121.

Parasuraman, A., Berry, L. and Ziethaml, V.A. (1988), "SERVAQUAL: a multiple item scale for measuring consumer perception for service quality", Journal of Retailing, 64(1), pp. 12-40.
Parasuraman, A., Zeithaml, V.A. and Berry, L.L. (1985a), "A conceptual model of service quality and its implication", Journal of Marketing, 49, Fall, pp. 41-50.

Parasuraman, A., Zeithaml, V.A. and Berry, L.L. (1985b), "Alternative scales for measuring service quality: a comparative assessment based on psychometrics tests and diagnostic quality in hotels", International Journal of Hospitality Management, 26, pp. 840-53.

Radder, L. and Han, X. (2015), "An examination of the museum experience based on Pine and recommending behaviour in lodging decisions", Journal of Hospitality and Leisure Marketing, 2, pp. 3-22.

Schofield, R. and Breen, L. (2004), "Suppliers do you know your customers?",International Journal of Quality and Reliability Management, 23(4), pp. 390-408.

Sheth, J.N., Newman, B.I. and Gross, B.L. (1991a), Consumption Values and Market Choice, South Western Publishing, Cincinnati, $\mathrm{OH}$.

Sugiyono. (2014). Metode Penelitian Administrasi. Bandung: Alvabeta

Svensson, G. (2006), "Interactive interface of service quality", European Business Review,18(3), pp. 243-257.

Sweeney, J.C. and Soutar, G. (2001), "Consumer perceived value: the development of multiple item scale", Journal of Retailing, 77(2), pp. 20320.

Sweeney, J.C. and Webb, D. (2002), "Relationship benefits: an exploration of buyer-supplier dyads", Journal of Relationship Marketing, 1(2), pp. 77-92.

Sweeney, J.C., Soutar, G. and Johnson, L.W. (1999), "The role of perceived risk in the quality value relationship: a study in a retail environment", Journal of Retailing, 75(1), pp. 77-105.

Worsfold Kate, F. R. M. R. M. and T. A. (2016). Satisfaction, value and intention to return in hotels. Intenational Journal of Contemporary Hospitality Management, 28(11). https://doi.org/ http://dx.doi.org/10.1108/MRR-09-2015-0216

$\mathrm{Wu}$, H.-C. (2014). The effects of customer satisfaction, perceived value, corporate image and service quality on behavioral intentions in gaming establishments. Asia Pacific Journal of Marketing and Logistics, 26(4), 540-565. https://doi. org/10.1108/APJML-03-2014-0049.

Zameer, H., Tara, A., Kausar, U., \& Mohsin, A. (2015). Impact of service quality, corporate 
image and customer satisfaction towards customers' perceived value.International Journal of Bank Marketing, 33(4), 442-456. https://doi.org/ http://dx.doi.org/10.1108/JJBM-01-2014-0015
Zeithaml, V.A. and Bitner, M.J. (1996), Services Marketing, McGraw-Hill, New York, NY.

Ziethaml, V. A., Bitner, M. J., \& Gremler, D. D. (2009). Service marketing. 